\title{
Museu Paulista: espaço de evocação do passado e reflexão sobre a história*
}

Cecilia Helena de Salles Oliveira

Museu Paulista da USP

enraizamento do Museu na cidade.

[...] O principal ponto de atração de todos os visitantes da cidade é o lpiranga, o magnífico monumento erigido em 1885 no lugar onde foi proclamada a Independência do Brasil em 1822. E a mais bela realização da arquitetura brasileira, planejada não só para comemorar esse glorioso evento mas também para servir como 'instituição de conhecimentos'. O Museu do lpiranga possui tesouros de grande interesse histórico e científico; valiosas e curiosas relíquias e também algumas das melhores pinturas de artistas brasileiros [...]

Escritas em 1902 por Marie Robinson Wright', essas impressões conservam ainda enorme atualidade, pois além de referencial físico e simbólico do traçado urbano paulistano, o Museu Paulista é o mais visitado da cidade e um dos mais freqüentados do Brasil, ocupando lugar cativo nos mapas, guias e demais publicações de divulgação voltados para a descrição histórica e turística de São Paulo² (FIGURA 1).

As relações que desde os fins do século XIX se estabeleceram entre o

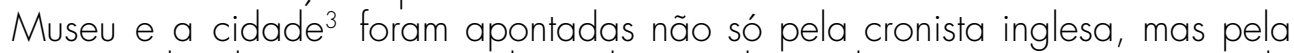
imprensa local e por memorialistas do período que buscavam, em momento de visível transformação econômica e social, demarcar as dimensões e singularidades de São Paulo ${ }^{4}$. Entretanto, talvez os depoimentos mais precisos e evidentes desses vínculos estejam nos Relatórios de cunho institucional apresentados ao governo do Estado de São Paulo por Hermann Von Ihering, primeiro diretor do Museu Paulista entre 1894 e 1916, e por Afonso d' Escragnolle Taunay, que o sucedeu ${ }^{5}$.

Ihering e Taunay não compartilhavam a mesma perspectiva museológica, e as divergências que os distanciavam estavam pautadas não só nas conjunturas políticas singulares que nortearam suas respectivas gestões, como em concepções

\begin{abstract}
* Este ensaio foi originalmente um dos capítulos da tese de Livre-Docência, "O espetáculo do Ypiranga: mediações entre história e memória", que defendi no Museu Paulista/USP, em 2000. Com alterações e acréscimos foi apresentado durante a IV SEMANA DE MUSEUS DA USP, em agosto de 2003.
\end{abstract}

1. WRIGHT, Marie Robinson.The New Brazil (1902). Citação de Ernani da Silva Bruno no livro Memória da Cidade de São Paulo Depoimentos de moradores e visitantes, 1553/1958. São Paulo: Prefeitura Municipa/DPH, 1981. p. 136-137.

2. A partir de 1999 e até 2002, conforme dados disponíveis no Museu Paulista, a visitação manteve-se no patamar de 250 mil pessoas/ano. Apenas para comparação,no mesmo período o MAE/USP, recebeu em média 60 mil visitantes/ano. 
3. Sobre a organização e proliferação de museus e de preservação patrimonial e suas vinculações com o processo de urbanização, consultar: MENESES, Ulpiano Toledo Bezerra de. O museu na cidade/a cidade no museu: para uma abordagem histórica dos museus de cidade. Revista Brasileira de História, São Paulo,ANPUH/Marco Zero, v. 5 , n. 8/9, p. 197-206, set/ 1984-abril/1985; CHOAY, Françoise. A alegoria do patrimônio. Trad. L.V. Machado. São Paulo: UNESP/ Estação Liberdade, 2001; MENEGUELLO, Cristina. Da ruína ao edifício. cientificas dotadas de historicidade e centradas em áreas do saber diferentes, no caso as ciências naturais e a ciência da história ${ }^{6}$. No entanto, suas posições não eram inteiramente excludentes como também não o foram os acervos dos quais tinham se tornado curadores. O fato de lhering ser zoológo não fez a instituição e seu diretor avessos aos acervos de caráter histórico. E se Taunay buscou transformar - Museu Paulista em um museu de história que obedecesse aos princípios e procedimentos historiográficos e estéticos de sua época, isto não quer dizer que tivesse se desvencilhado do imenso acervo de história natural que, em certa medida, fazia parte da história nacional, pois exprimia o ambiente no qual se dera a formação da "civilização brasileira"7

A despeito do museu projetado por thering inspirar-se nitidamente em seus congêneres norte-americanos, e apesar de Taunay procurar em museus europeus, particularmente franceses, suas fontes de referência ${ }^{8}$, havia entre eles um aspecto em comum: a preocupação em relação à dimensão pedagógica e "civilizatória" do Museu que dirigiram, quer no sentido de interpretá-lo como local destinado à "instrução pública" e à formação de "cidadãos", quer considerando-

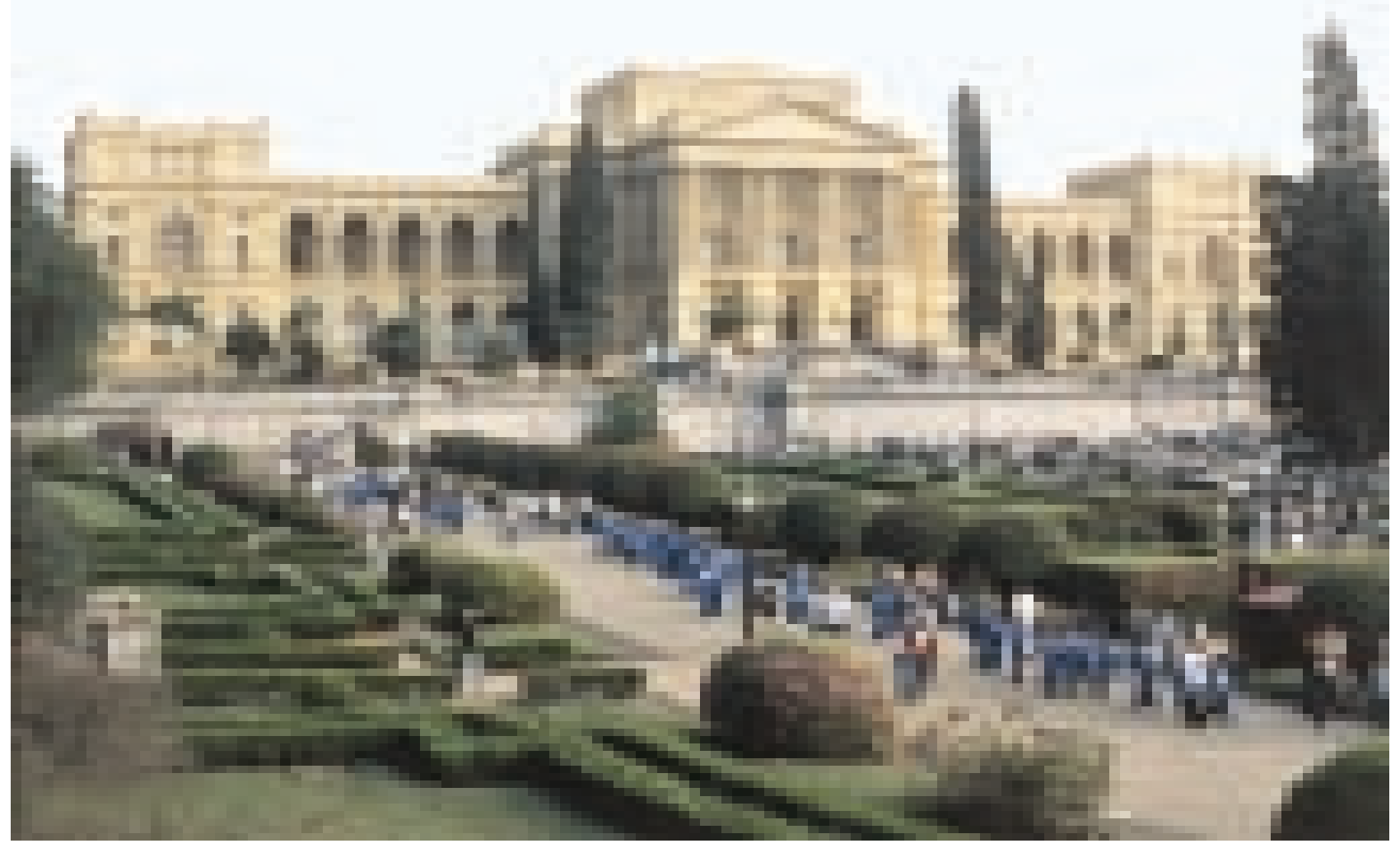

FOTOGRAFIA 1 - Fotografia produzida em 7 de setembro de 2000, registrando movimentação de público no Parque da Independência. Acervo do Museu Paulista da USP. Fotografia de José Rosael. 
- como lugar propício para a formulação de axiomas "verdadeiros" sobre a natureza, a história e a vida humana?. Ambos indicaram em seus Relatórios a imponência do edifício e seu caráter de memorial à Independência, mas associaram a importância da instituição que geriram sobretudo a três condições: os serviços que prestava do ponto de vista da produção e difusão de conhecimentos científicos; a presença constante de "visitantes ilustres", como representantes diplomáticos, homens de ciência e políticos de prestígio; e a afluência de uma "multidão" que freqüentava as exposições.

Estimativas elaboradas por von lhering, em 1906, indicaram que, entre 1895 e 1905, o número de freqüentadores atingira uma média anual de 40 mil pessoas. As únicas exceções teriam ocorrido em 1901 e 1902 em decorrência da " comunicação péssima que a antiga Companhia Viação Paulista estabelecia entre a cidade e o arrabalde do lpiranga. Os bondes acanhados, morosos e de intervalos enormes gastavam neste trajeto uma hora inteira". A partir de 1903, todavia, com o funcionamento dos "tranways elétricos" esta situação teria sido em parte corrigida. Em compensação, porém, Von lhering indicava que os "preços
Neogótico, reinter-pretação e preservação do passado na Inglaterra vitoriana. 2000. Tese (doutorado) - Universidade de Campinas, Campinas; POULOT, Dominique (Ed.). Patrimoine et modernité. Paris: L'Harmattan, 1998.

4. Sobre as transformações físicas e sociais em curso na cidade de São Paulo durante o século XIX e o início do século XX, consultar, especialmente:DÉNIS,Pierre. Le Brésil ao XXe. Siècle (1906).Paris:Armand Colin, 1910; Coleção de A Província de São Paulo, edições referentes especialmente à

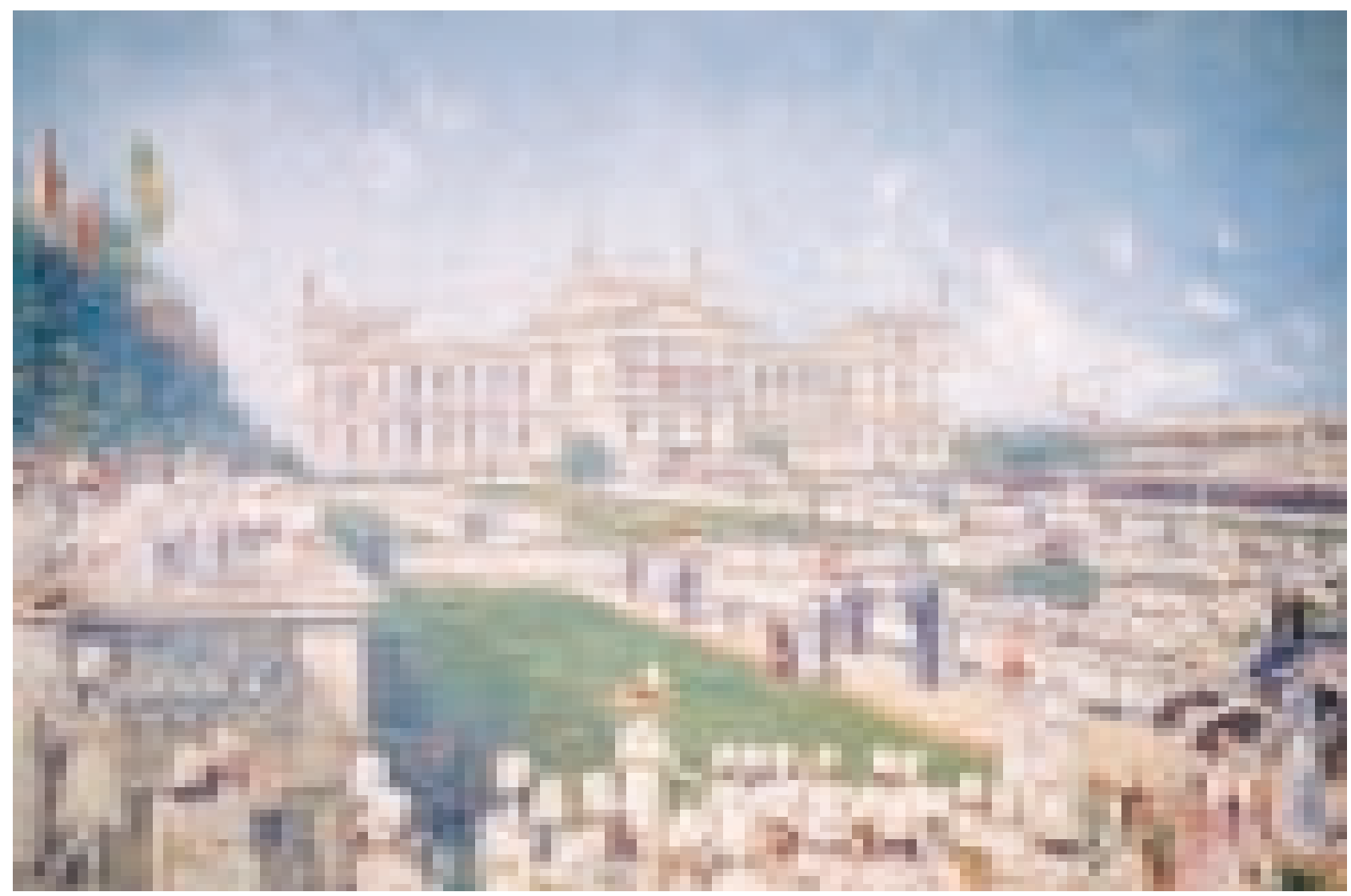

FOTOGRAFIA 2 - Augustin Salinas Y Teruel (1869-1923). Museu do lpiranga, 1912. Óleo sobre tela, $99 \times 150$ m. Acervo da Pinacoteca do Estado. Reprodução de José Rosael. 
década de 1880. Exemplares conservados no Museu Paulista/USP; MORSE, Richard.Formação bistórica de São Paulo.São Paulo: Difel,1970;QUEIROZ,Suely Robles.São Paulo. Madrid, 1992; Cadernos de História de São Paulo. São Paulo, Museu Paulista/USP, 1992/1996, v. 1-5; BRESCIANI, Maria Stella (Org.). Palavras da cidade. Porto Alegre:UFRGS, 2001.

5.Os Relatórios referentes ao Museu Paulista durante a gestão de Hermman Von Ihering encontram-se publicados nos primeiros volumes da Revista do Museu Paulista, 1895/ 1915. Quanto aos Relatórios referentes à direção de Afonso d'Escragnolle Taunay, podem ser consultados no Serviço de Documentação Textual e Iconografia do MP/USP.

6. A esse respeito consultar especialmente:ELIAS,Maria José. Museu Paulista: memória e história. 1996. Tese (Doutorado) - Universidade de São Paulo, São Paulo, 1996; BREFE, Ana Cláudia Fonseca. Um lugar de memória para a nação. $\mathrm{OMu}-$ seu Paulista reinventado por Affonso d'Escragnolle Taunay. 1999.Tese (Doutorado) - Universidade de Campinas, Campinas, 1999; ALVES,Ana Maria deAlencar. O Ipiranga apropriado. Ciência, política e poder. $\mathrm{O}$ Museu Paulista, 1893/1922. São Paulo: Humanitas/ PPGHS/USP, 2001.

7. Sobre as especificidades dos museus de história natural no século XIX, consultar: LOPES, Maria Margareth. O Brasil descobre a pesquisa científica. Os museus e as ciências naturais no século XIX.São Paulo:Hucitec, 1999. Além disso, impor- elevados" das passagens representavam "empecilho para visitação mais acrescida [...]" $]^{\prime 0}$. Em 1914, comentava que a quantidade de público havia se mantido ao longo desses anos, ressaltando, porém, que em 1912, por ocasião das festividades dos noventa anos da Independência, o Museu recebera somente no dia 7 de setembro mais de 10 mil crianças' 11 (FIGURA 2).

E na mesma direção situam-se observações feitas, também em 1912, pelo memorialista britânico Archibald Stevenson Forrest:

[...] Aos domingos e feriados, o passeio favorito do povo - italianos, negros, portugueses, alemães, paulistas e ingleses - é ir de carro da Praça da Sé até os jardins e o Museu do Ipiranga. A viagem ocupa cerca de meia hora, e o percurso é feito saindo-se do Largo 7 de setembro, descendo pela rua da Glória, com suas pequenas casas uniformes, passando pelo Matadouro, e seguindo pelas alamedas arborizadas de ambos os lados e que vão em direção aos bairros, onde os edifícios avançam em todas as direções e os operários executam suas tarefas apesar de ser domingo... A maioria dos passageiros desce para os jardins do lpiranga, situados em terreno de largas calçadas que vai se elevando suavemente marginado por ciprestes, canteiros de flores muito bem tratados e todos os tipos de arbustos. O Museu erigido como monumento para comemorar o histórico acontecimento, é uma construção imponente e bem desenhada, com belas escadas e luxuosas galerias em uma das quais está um enorme quadro ilustrando o episódio "Independência ou Morte! [... $]^{12}$.

Em certa medida, a imagem que o cronista projetou do "povo" iria ao encontro de anołações elaboradas por Taunay anos depois. No Relatório referente a 1918, comunicava ao secretário do Interior que, em 1917, a freqüência ao Museu havia sido "excepcional", superando as 50 mil pessoas e equiparando-se à de 1912. Comentava que seria "conveniente" a cobrança de "módicas entradas" às 3 as. e 5 as. feiras, permanecendo a gratuidade aos domingos, uma vez que tal atitude afetaria apenas "pessoas de certa categoria". Os visitantes dos dias de semana, ponderava, " não são geralmente operários nem proletários $[\ldots]$ " 13 .

Já em 1923, Afonso de Taunay estimava que, no dia 7 de setembro de 1922, mais de 20 mil pessoas tinham percorrido as dependências do edifício. Nessa ocasião, dentre as comemorações do Centenário da Independência, deuse a reabertura do Museu ao público, depois de quase dois anos de fechamento, período consumido com a preparação e realização parcial das obras que modificaram a fisionomia interna do palácio-monumento ${ }^{14}$ (FIGURA 3).

Conforme registrou, a afluência de curiosos foi de tal ordem que, em razão do "aperto", várias vitrinas se quebraram, e apesar da preocupação demonstrada com essas ocorrências, o então diretor delas se serviu para comprovar a admiração provocada pelo Museu junto ao público e para solicitar ao governo o aumento de verbas e a agilização nas obras de embelezamento das cercanias da instituição. Em sua avaliação, entre setembro e dezembro de 1922, perto de 120 mil pessoas visitaram as salas de exposição e muitas outras poderiam ter ali estado se as vias públicas estivessem calçadas e se a lama causada pelas chuvas não o tivessem obrigado a manter o Museu fechado por vários dias ${ }^{15}$.

Outras fontes, entretanto, sugerem que as estimativas de Taunay foram exageradas. Um dos depoimentos expostos e problematizados por Ecléa Bosi na obra Memória e Sociedade, o de Da. Brites, contém significativa passagema esse respeito:

[...] Em 1922, no Centenário da Independência disseram que iam aprontar o Museu do lpiranga, que iam trazer fogos de artifício. Choveu a semana inteira, nós fomos pelo 
Cambuci afora de automóvel para alcançar o Museu, não pudemos passar por causa da chuva e fogos de artifício ninguém viu. Era só lama e breu. Os festejos foram no Rio de Janeiro $[\ldots]^{16}$.

Ao mesmo tempo em que desfaz a impressão provocada pela documentação institucional que leva à suposição de que o processo de reformas e os festejos tinham se realizado efetivamente conforme planejado pelas autoridades públicas, a fala de Da. Brites evidencia a solidez da imagem criada em torno do Museu na sua juventude. Em meio a outras tantas lembranças de vida, Da. Brites resguardou aquele momento, mostrando os significativos vínculos afetivos que construiu com o lugar e com a instituição.

A leitura dessas fontes conduz a diversas questões, tais como, que relações haviam se estabelecido, desde os fins do século XIX e nas décadas tantes reflexões sobre as relações entre história natural, política e imaginário social foram formuladas por Maria Ligia Prado na obra América Latina no século XIX. Tramas, telas e textos. São Paulo: EDUSC/EDUSP, 1999, especialmente p. 179-ss, quando alia os estudos sobre a natureza e as interpretações sobre a natureza americana nos séculos XVIII e XIX com a construção de identidades nacionais.

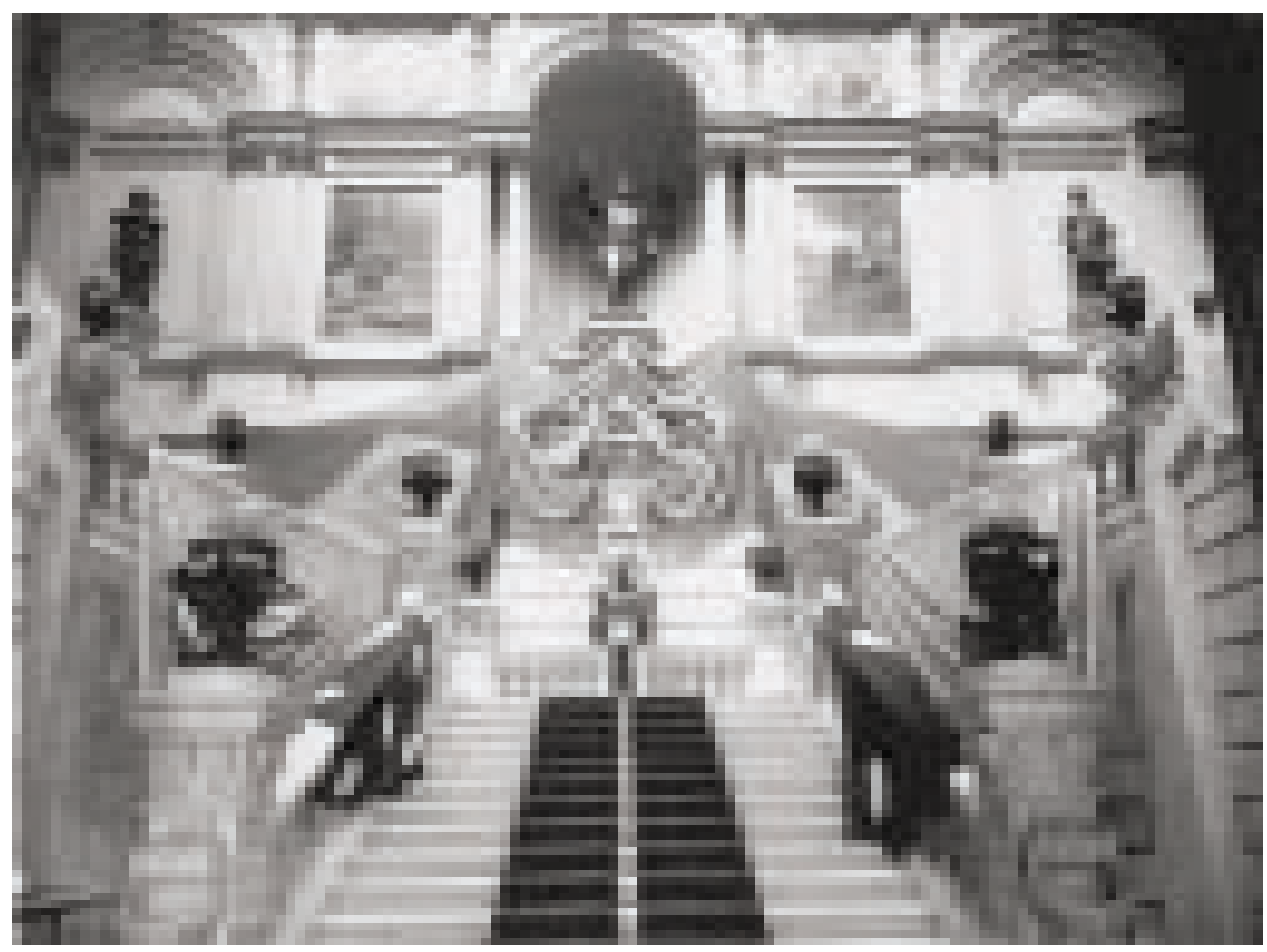

FOTOGRAFIA 3 - Registro da escadaria central do edifício do Museu Paulista, ornamentada para comemorações da Independência durante a gestão de Afonso de Taunay, c. 1924. Acervo do Museu Paulista da USP. Reprodução de José Rosael. 
8. Em obra já citada, Ana Maria deAlencarAlves mostra como von Ihering procurou seguir os procedimentos analíticos e expositivos propostos por George Brown Goode e aplicados no Museu Nacional dos Estados Unidos, o que coadunava com os desígnios políticos e científicos defendidos pelos governantes republicanos em São Paulo, logo após a organização do novo regime. Nesse sentido, o Museu Paulista foi concebido para ser um centro de ciência e de "ilustração" do povo. Já durante os primeiros anos da gestãoTaunay,em função dos preparativos para o Centenário da Independência e da gradual mudança que se impôs ao perfil da instituição, a principal inspiração foi buscada nos museus localizados na cidade de Paris, particularmente o Museu Carnavalet.Ver a esse respeito: OLIVEIRA, Cecilia Helena de Salles. $O$ Espetáculo do Ypiranga: mediações entre história e memória.2000.Tese (LivreDocência)-Museu Paulista, Universidade de São Paulo, São Paulo, 2000. cap.3.

9. Sobre os pressupostos da educação pública nos primórdios da República, ver:BITTENCOURT, Circe Maria F. Pátria, civilização e trabalbo. O ensino de História nas escolas paulistas, 1917/1939. São Paulo: Loyola, 1990; NAGLE, Jorge.A educação na primeira república.In: FAUSTO, Boris (Org.).História geral da civilização brasileira. São Paulo: Difel, 1970. tomo III, v. 2, p. 259-292.

10. O Museu Paulista nos anos de 1903 a 1905. Revista do Museu Paulista, São Paulo, 1907, v.VI. iniciais do século XX, entre o Museu e o público que o visitava e quem seriam esses visitantes? Os registros oficiais disponíveis valorizam números, e a linguagem genérica utilizada tanto nesses documentos quanto nos relatos de memorialistas opacifica uma possível compreensão da fisionomia dessa " multidão" qualificada ora como " pessoas de certa categoria", que nos dias dedicados ao trabalho dispunham de tempo livre, ora como "operários" e "proletários" que parecem ter tido presença marcante nos domingos de visitação gratuita e nos dias de celebração nacional. Nos Relatórios nomeiam-se personalidades que ocupavam lugares particularizados na esfera pública, como os membros do Automóvel Club e políticos pertencentes ao Partido Republicano Paulista, mas a não ser pela quantidade sempre relativa e por vezes exagerada - estão ausentes referências substanciais sobre o público, resguardando-se, porém, a imagem de que fortes liames emocionais e educacionais atrelavam o monumento à Independência, o Museu que ali fora organizado e os moradores da cidade.

Quais seriam os marcos da construção desses vínculos? Poderiam auxiliar a investigação da prática atual, compartilhada por milhares de pessoas anualmente, de visitar o Museu Paulista - o tão conhecido Museu do lpiranga? Para além dos aspectos lúdicos e, eventualmente, das imposições ensejadas por tarefas escolares ou compromissos profissionais, quais seriam os possíveis suportes culturais e políticos da "tradição" de visitar o Museu? E por que, particularmente por ocasião da data de 7 de setembro, essa visitação mantém-se não só constante como quantitativamente representativa?

Pontuando marcos de ritual evocativo

Pela documentação consultada é possível observar que a configuração de um espaço, na cidade de São Paulo, destinado às celebrações cívicas e às atividades lúdicas delineou-se com a construção, na década de 1880, do Monumento à Independência e, portanto, antes da inauguração do Museu, ocorrida a 7 de setembro de 1895. Nesse sentido, o edifício sob a forma de palácio erguido no Ipiranga revestiu-se de feições singulares. Originalmente idealizado durante o governo monárquico, por políiticos do Partido Conservador, foi por eles imaginado como "lugar de memória"17, projetado para que ali a sociedade registrasse voluntariamente lembranças e esquecimentos, reencontrando-os como suportes tangíveis de sua própria configuração políitica e simbólica. Criava-se, desse modo, um marco definitivo da Proclamação da Independência, assinalando-se de forma pública e visível um local evocativo do episódio e da fundação do Império.

A obra de alvenaria, com sua imponência, não demarcava apenas, porém, a autoridade irretocável de um "fato". Ensejava a "invenção de tradições", como observou Eric Hobsbawm, pois ao valorizar o 7 de setembro como ponto de inflexão da história nacional instituía saberes e práticas a partir dos quais institucionalizaram-se e propagaram-se rituais que ajudaram a conformar a constituição subjetiva da "comunidade imaginária" que é a nação ${ }^{18}$.

Considerando-se a pertinência dessas observações, seria possível interpretar a apropriação do monumento e sua transformação em Museu Paulista pelos republicanos jacobinos na década de 1890, como uma releitura e redirecionamento de comemoração do 7 de setembro "inventada" por 
monarquistas, então empenhados em galvanizar estratégias e iniciativas justificadoras da continuidade do Império, projeto que não lograram ver concretizado. Nesse sentido, a organização de uma instituição científica e de instrução popular, se procurava obliterar a memória da vinculação entre monarquia e origens nacionais, veio a reforçar o caráter celebrativo da construção bem como seu apelo popular. Isto porque buscou-se na aliança entre ciência e "relíquias" da história pátria a projeção da República, o que se evidencia na disposição, desde os primeiros governos republicanos, de promover às portas do Museu festejos cívicos anuais do 7 de setembro, reunindo militares e crianças, conforme registrou von lhering. Ao mesmo tempo, foi providenciada a colocação de uma escultura em gesso de Marienne no nicho principal da escadaria central do prédio ${ }^{19}$ (FIGURAS 4, 5).
11. IHERING, Hermann von. O Museu Paulista nos anos de 1910, $1911 \mathrm{e}$ 1912. Revista do Museu Paulista,São Paulo,Tomo IX, p. 8, 1914.

12. FORREST, Archibald Stevenson. A tour through southAmerica (1912).In: BRUNO, Ernani da Silva. ob. cit., p. 172-173

13. RELATÓRIO referente ao ano de 1917 , apresenta-

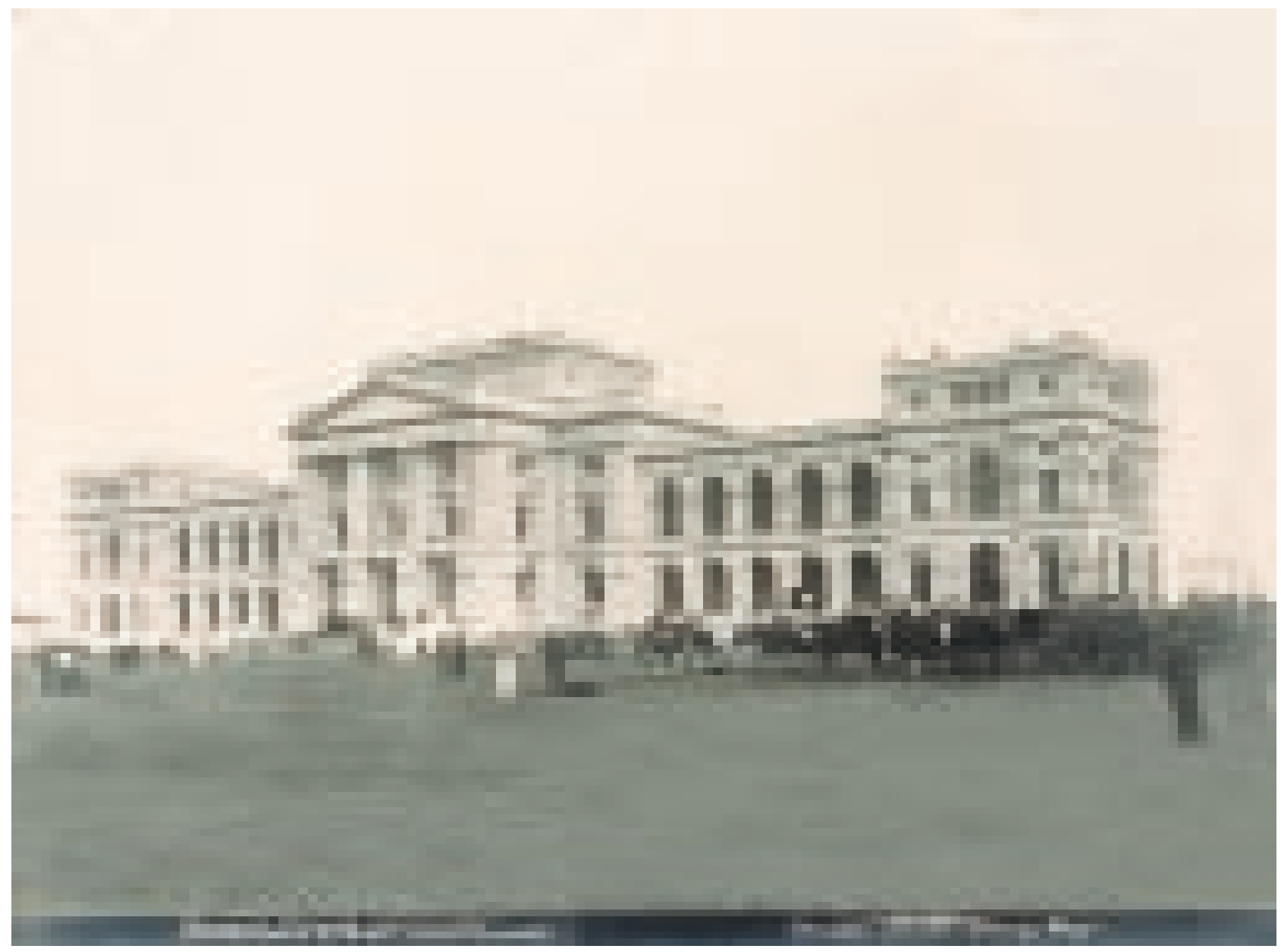

FOTOGRAFIA 4 - Festejo à frente do edifício-monumento do lpiranga, c. 1890. Acervo do Museu Paulista da USP. Restauração óptica de João Sócrates de Oliveira. Reprodução de José Rosael. 


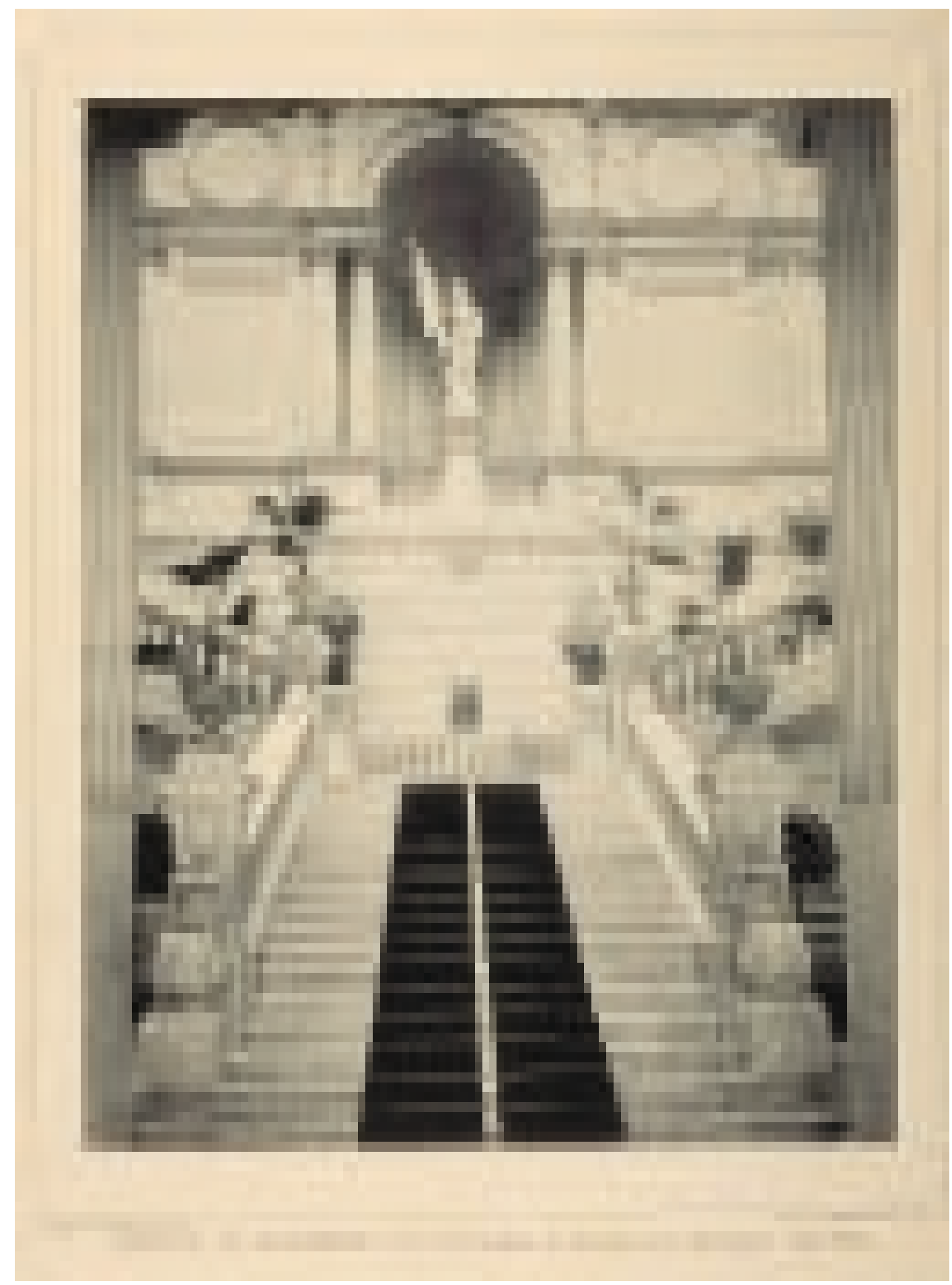

FOTOGRAFIA 5 - Registro do interior do Museu Paulista, durante a gestão de Hermann von Ihering. Ressalta-se no nicho da escadaria central do edifício a figura de Marienne, representando a República, c. 1898. Acervo do Museu Paulista /USP. Foto Guilherme Gaensly. Reprodução óptica João Sócrates de Oliveira. Reprodução fotográfica de José Rosael. 
Com Taunay à frente da administração, o Museu foi sendo gradualmente preparado para alterar seu perfil. $\bigcirc$ historiador das bandeiras e da história de São Paulo foi se formando simultaneamente ao hábil diretor que fazia parte de campo político muito diferente daquele de seu antecessor. As obras de reformas e decoração interna do edifício não expressavam apenas um projeto de comemorações do Centenário da Independência. Mais do que isso, Taunay pretendia - e foi bem sucedido - ampliar o raio de inserção social do Museu por meio de uma interpretação que procurava superar as antigas irredutibilidades entre monarquistas e republicanos. A síntese da história do Brasil e de São Paulo, idealizada nas décadas de 1920 e 1930 e inscrita nos espaços interiores do palácio-monumento sinaliza para uma leitura conciliatória, que recupera as tradições monárquicas para colocá-las a serviço da República e do presente que protagonizava. Por outro lado, em função dos festejos de 1922 e também da compreensão de que ao Museu cabia papel predominante na educação popular, o então diretor procurou mobilizar objetos, registros iconográficos e documentos textuais para que a instituição fosse reconhecida como referência e "autoridade" na difusão do conhecimento histórico, transformando-se em lugar cuidadosamente arranjado e conservado para que o público tivesse a oportunidade de "ver a verdade da história". Ou seja, tornaram-se mais notórios os investimentos da direção do Museu em relação aos visitantes, o que certamente ampliou seu número, mas significou uma ação mais enérgica em relação a "ensinar o olho a olhar"20 (FIGURAS 6, 7).

Passados cento e dez anos de criação, ainda a prática da visitação sistemática ao Museu encontra suportes para atualizar-se, particularmente nos dias de comemoração cívica, como a data do aniversário da cidade ou a data da Independência Entre 1992 e 1998, por exemplo, o Museu recebeu, levando-se em conta apenas $\circ 7$ de setembro, contingente bastante significativo de visitantes que variou entre 5 e 10 mil pessoas/dia. A recriação dessa forma de manifestação popular suscita reflexões e questionamentos, especialmente no tocante à possibilidade de interrogar as interpretações que visitantes elaboram a respeito da lndependência e das expectativas que alimentam sobre o Museu e suas significações.

Indagar sobre o sentido que os visitantes atribuem à sua prática conduz a uma primeira aproximação em relação aos modos pelos quais a memória coletivamente transmitida e enraizada se manifesta no presente. Representa também um recurso para mapear os perfis do público freqüentador e os vínculos que mantém com o Museu e com as exposições que este oferece.

\section{matizado universo de visitantes e a ressignificação do Museu e das tradições}

Uma observação apressada da área de exposições nos dias da semana poderia provocar a impressão de que a maciça maioria dos freqüentadores é composta por escolares, em virtude da aglomeração de crianças e jovens e das filas de escolares dirigidas por professores ou por monitores de agências de turismo, expediente usado por muitas instituições tanto públicas quanto privadas. Porém, também nesses dias e especialmente nos finais de semana e nos feriados, salas de exposição e galerias são ocupadas por famílias, jovens casais com crianças do por Afonso d'Escragnolle Taunay, a 2 de janeiro de 1918, a Oscar Rodrigues Alves, Secretário do Interior. Serviço de Documentação Textual e Iconografia do MP/USP.

14. Sobre o ambiente intelectual de São Paulo na época e sobre alguns dos aspectos das comemorações de 1922, consultar: SEVCENKO, Nicolau. $O r$ feu extático na metrópole. São Paulo, sociedade e cultura nos frementes anos 20. São Paulo: Companhia das Letras, 1992; LUCA, Tania Regina de. $A$ Revista do Brasil: um diagnóstico para a (n)ação. São Paulo: UNESP, 1999; FERREIRA,Antonio Celso. A epopéia bandeirante: letrados, instituições, invenção histórica, 1870/ 1940. São Paulo: UNESP, 2002. Especificamente sobre o processo de reformas no Museu Paulista e a concepção e execução da decoração interna do prédio, que permanece até hoje, consultar, além das obras já citadas de Maria José Elias,Ana Claudia Brefe e Ana Maria de Alencar Alves, a dissertação de mestrado de José Costa de Oliveira Filho. $O$ Edifício do Museu Paulista: um pouco da história do edifício-monumento de Bezzi.São Paulo,USP, 2000; e o artigo O Museu Paulista da USP e a memória da Independência que publiquei nos Cadernos do CEDES, São Paulo, Cortez; Campinas, v. 22,n. 58, dez. 2002.

15. RELATÓRIO referente ao ano de 1922, apresentado porAfonso d'Escragnolle Taunay a 23 de janeiro de 1923 ao Secretário do Interior, Alarico Silveira. 


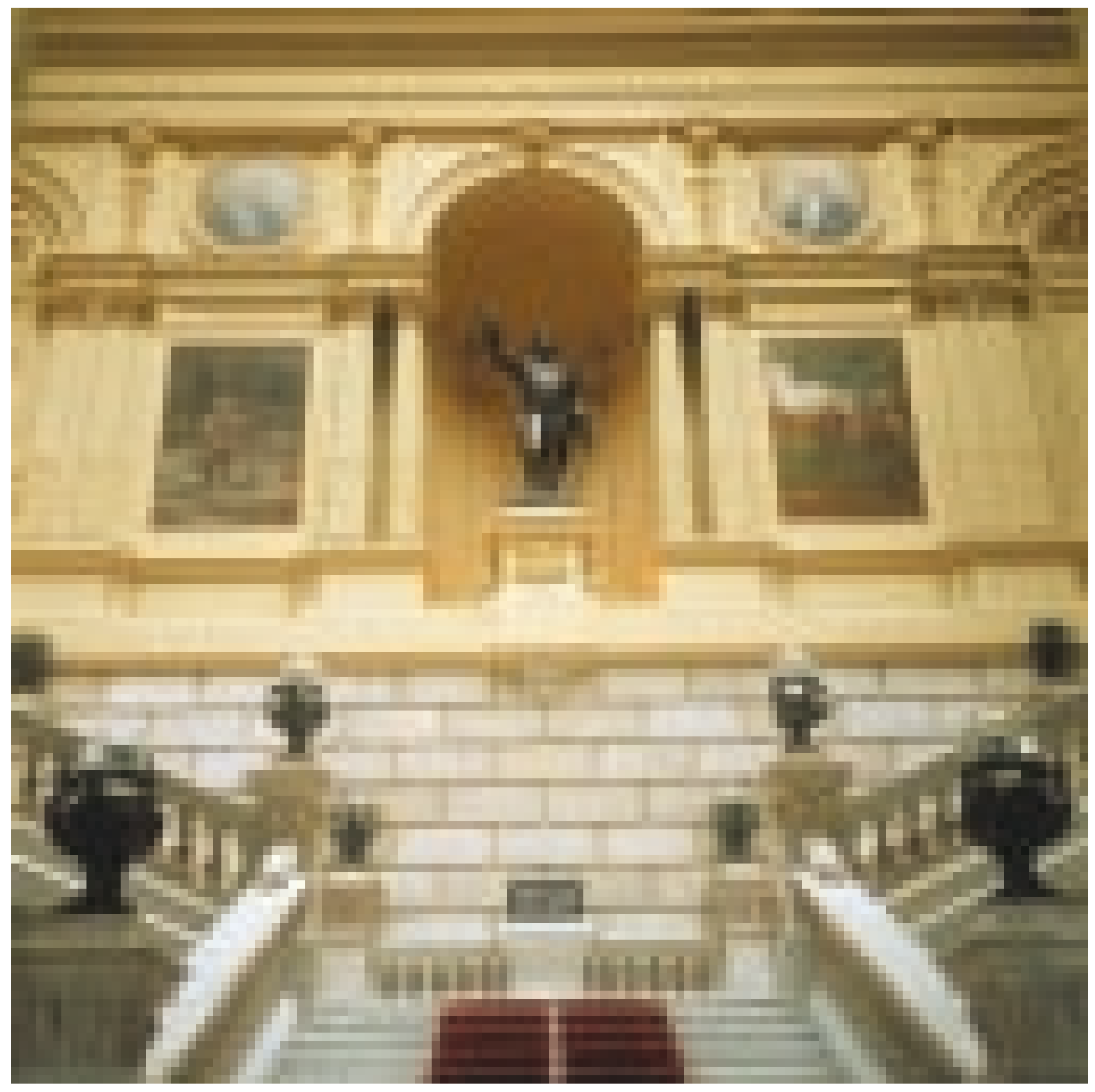

FOTOGRAFIA 6 - Registro do interior do Museu Paulista na atualidade, ressaltando-se no nicho da escadaria central do edifício a escultura monumental de D. Pedro I, confeccionada em bronze por Rodolfo Bernardelli. Acervo do Museu Paulista da USP. Fotografia de José Rosael. 


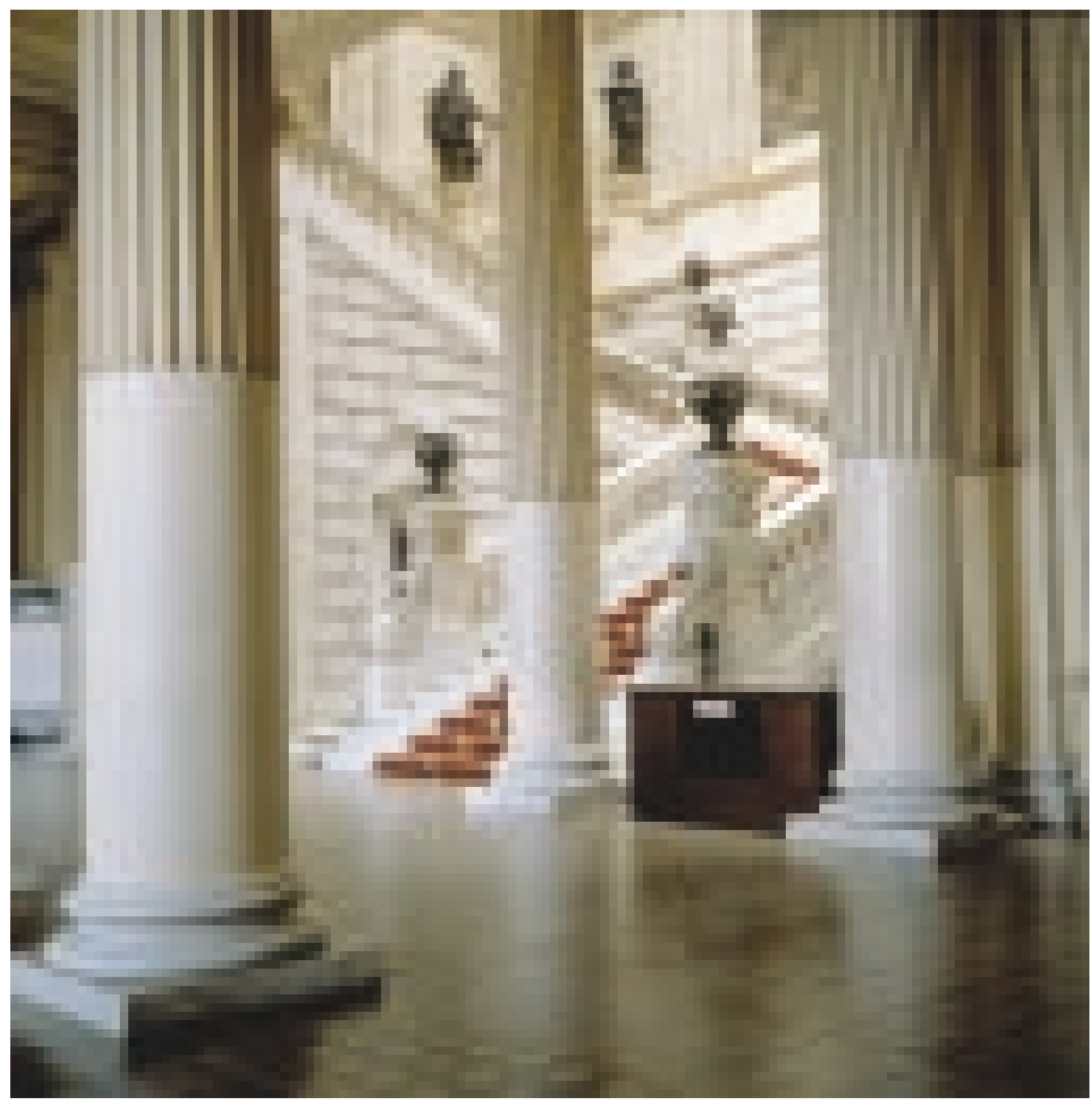

FOTOGRAFIA 7 - Ângulo do saguão do Museu Paulista, na atualidade, ressaltando-se a escadaria central, ornamentada com ânforas de cristal, contendo as águas de rios brasileiros, bem como esculturas em bronze de bandeirantes. Acervo do Museu Paulista da USP. Fotografia de José Rosael. 
16. BOSI, Ecléa. Memória e sociedade. Lembranças de velhos. São Paulo: TA Queiróz, 1983. p. 251.

17. A expressão foi formulada por Pierre Nora para analisar as relações entre história e memória no mundo contemporâneo e para se referir, especificamente, ao movimento de preservação/construção de monumentos comemorativos da nação francesa na época do bicentenário da Revolução Francesa. Ver: NORA, Pierre (Org.) Les Lieux des Mémoires. Paris: Gallimard, $1984,1^{\circ} \mathrm{v}$. p.VIII-XLII. Consultar,também, as considerações críticas feitas sobre a questão por François Hartog no artigo Tempo e História: como escrever a história da França hoje? História Social. Revista do PPGH/ UNICAMP, n. 3, 1996.

18. HOBSBAWM, Eric; RANGER, Terence (Org.). A invenção das tradições. Trad. C. Cavalcanti. Rio de Janeiro: Paz e Terra, 1984 p. 9-23. Sobre a expressão "comunidades imaginadas" e suas significações, consultar: ANDERSON, Benedict. Comunidades imaginadas. Reflexões sobre el origem y la difusión del nacionalismo. México, Fondo de Cultura Econômica, 1993.

19. Essas reflexões fundamentam-se em discussão que desenvolvi na tese de Livre-Docência $O$ Espetáculo do Ypiranga, já citada.

20. Id., ibid. Consultar a esse respeito, também, as obras de Maria José Elias e deAna Cláudia Bref,bem como Cadernos do CEDES, todos já indicados. de colo, turistas estrangeiros e de diferentes regiões do País, grupos de adolescentes e mesmo pessoas solitárias que, conforme pude observar, muitas vezes detêm-se durante longo tempo para admirar vitrinas e acervos. Em 1993, por exemplo, $60 \%$ dos 320 mil visitantes daquele ano não era formada por estudantes e, em 1997, dos 210 mil visitantes apenas 34\% foi de escolares e professores. Nos últimos anos essa situação não se alterou.

As entrevistas que realizei foram colhidas entre 1992 e 1995, ${ }^{21}$ e na definição do universo de informantes o único critério utilizado foi o de serem pessoas dispostas a percorrer as galerias e salas do Museu Paulista sem qualquer tipo de obrigatoriedade, seja de ordem escolar seja de outra natureza. As primeiras conversas foram produzidas entre julho e agosto de 1992 e optei pelo uso do gravador, pois pareceu-me essencial não "perder" palavras ou inflexões. Além disso, a escolha dos informantes foi aleatória, de modo a que pudesse registrar as falas de pessoas diferenciadas em termos de faixa etária, condições de vida e de trabalho. Sempre que me aproximei de um visitante, tomei o cuidado de identificarme e de esclarecer os motivos da entrevista, consultando-o sobre sua disponibilidade de colaborar e recebi poucas negativas, em razão, talvez, da tentativa de preservar os entrevistados, não solicitando a declinação de seus nomes verdadeiros.

O roteiro de entrevistas, inicialmente adotado, procurava levantar informações a respeito de idade, profissão, escolaridade e local de residência, incluindo indagações sobre a visita ao Museu, sobre os acervos, sobre a Independência, bem como a respeito das ligações entre o episódio e a instituição.

O roteiro não foi apresentado por escrito, servindo apenas de balizamento para que a conversa pudesse fluir sem dispersão de assuntos. Durante as primeiras conversas, pude constatar que o roteiro-piloto era muito extenso e que, além de repetitivas, algumas indagações poderiam "induzir" as respostas, comprometendo os resultados que desejava alcançar. Houve ocasiões em que optei por não interromper a narrativa, a despeito disso representar a não-formulação de todas as perguntas ao entrevistado. Assim, o roteiro passou por modificações e adequações e, em sua segunda versão, à exceção de informações relativas à idade, profissão, escolaridade e local de residência, todas as anteriores interrogações foram concentradas em quatro pontos que me pareciam essenciais: a) a freqüência da visitação ao Museu Paulista; b) o significado da Independência e das comemorações no dia 7 de setembro; c) as peças em exposição mais representativas da Independência; d) a importância do Museu Paulista em relação à Independência.

Procurei não intervir abertamente na fala dos entrevistados, apesar de reconhecer que minha ação na área de exposições e a direção dada às perguntas representavam uma ingerência direta no desenrolar das ações. Não há como negar que as respostas foram concatenadas pela mediação de circunstâncias de momento e que as opiniões fundamentaram-se em vivências e saberes que vieram à tona avivados por essa situação peculiar. Ou seja, aprendi que o papel do entrevistador é preponderante e que minha presença afetou cada um dos depoimentos colhidos.

Procurei inspirar-me em alguns procedimentos do campo de investigação denominado de história oral, e sob esse ponto cabe lembrar duas pertinentes observações formuladas por Janotti e Rosa ${ }^{22}$. A primeira diz respeito ao fato de que o "historiador continua a comandar o processo de conhecimento ao selecionar depoentes, recortar temas, reescrever falas e construir explicação histórica a partir 
do que generosamente the foi oferecido". A segunda é que "inerente aos depoimentos orais, há uma pluralidade de aspectos subjetivos que os diferenciam das fontes escritas, envolvendo uma forte carga emocional, que interfere na narrativa e na sua interpretação" 23 . Nesse sentido, além de envolver-se na criação de documentos, cabe ao historiador levar em conta que "os testemunhos orais não são simples registros, mas produtos culturais complexos, incluindo inter-relações cuja natureza não é fácil de compreender", pois entrelaçam "memórias, experiências passadas, situações presentes e representações culturais do passado e do presente" 24 .

Realizei mais de quarenta entrevistas, incluindo neste número as obtidas durante o período de aplicação e experimentação do roteiro-piloto. Mas debruceime sobre trinta e dois depoimentos, colhidos a partir da reformulação das questões. E é importante esclarecer que o procedimento adotado, de nenhum modo se assemelhou a uma coleta de dados ou teve pretensões de amostragem estatística. objetivo primordial das entrevistas foi o de proporcionar um levantamento de problemas históricos relacionados à memória da Independência inscrita no Museu Paulista. Por essa razão, o conteúdo das entrevistas e as inferências que ensejaram representam uma primeira aproximação em relação ao estudo das formas de recriação e difusão, nos dias de hoje, de um imaginário político que investiu le investe) de sentidos múltiplos um episódio particular de nossa história.

Por outro lado, na formulação das entrevistas e e em seu estudo, foram fundamentais as reflexões e encaminhamentos teórico-metodológicos construídos por Ecléa Bosi. Na conhecida obra Memória e Sociedade, a autora discute, entre outras considerações, a impossibilidade de se compreender os processos subjetivos e sociais de rememoração e esquecimento como se fossem livres e espontâneos. Recuperando e desdobrando observações de Halbwachs, que se deteve sobre os "quadros sociais da memória", alerta para o fato de que esta não permaneceria adstrita ao "mundo da pessoa", mas estaria entrelaçada ao universo das instituições e das heranças culturais incorporadas e reformuladas ao longo da própria formação e exteriorização do sujeito. "A memória do indivíduo", explicita, "depende de seu relacionamento com a família, com a classe social, com a escola, com a lgreja, com a profissão; enfim, com os grupos de convívio e os grupos de referência peculiares a esse indivíduo". E completa: é a vida atual do sujeito que desencadeia o curso da memória.

\footnotetext{
Se lembramos, é porque os outros, a situação presente nos fazem lembrar [...] $\mathrm{Na}$ maior parte das vezes, lembrar não é reviver, mas refazer, reconstruir, repensar com imagens e idéias de hoje, as experiências do passado. A memória não é sonho, é trabalho $[. .]^{25}$
}

Nesse sentido, os depoimentos foram suscitados e recolhidos sob condições precisas. Coube ao pesquisador sugerir aos sujeitos entrevistados a verbalização das lembranças que haviam retido ou produzido sobre a Independência e isso aconteceu em um espaço-tempo singular: uma visita ao Museu histórico mais antigo de São Paulo e que se tornou conhecido por suas vinculações com o episódio de 1822. Mas essa particularidade não constitui, a meu ver, um aspecto negativo. Penso que a riqueza das entrevistas e, em muitos casos, o fluir da "imaginação" se deveram precisamente a uma injunção entre os questionamentos formulados, o movimento subjetivo de rememoração e a relação
21. Conforme apontado anteriormente, essas reflexões fundamentam-se em minha tese de LivreDocência.Consultar,especialmente os três capítulos iniciais, bem como os depoimentos integrais dos visitantes que entrevistei, editados nas p. 93-112

22. JANOTTI, Maria de Lourdes; ROSA, Zita de Paula. História oral: uma utopia? Revista Brasileira de História, São Paulo, $\mathrm{n}$. 25/26, p. 3-ss., 1992/1993.

23. Id., ibid., p. 12.

24.SCHWARZTEIN, Dora. História oral, memória e histórias traumáticas. História Oral, São Paulo,n. 4 , p. 73-ss, 2001.

25. BOSI, Ecléa. Ob.cit.,p. 17. Consultar da mesma autora $O$ tempo vivo da memória. Ensaios de psicologia social. São Paulo: Ateliê Editorial, 2003. 
26. Id. Ibid., p. 17-ss.

27. Referências acerca das complexas mediações entre práticas e representações podem ser encontradas em:LEFORT, Claude. As formas da história. Trad. M. Chauí e L.R.Salinas Fortes. São Paulo: Brasiliense, 1979, especialmente capítulos XI e XIII.São pertinentes, também, as considerações formuladas por Baczko sobre a impossibilidade de dissociar relações de poder e imaginários sociais e sobre os imaginários sociais como modos de regulamentação da vida coletiva historicamente produzidos. Ver: BACZKO, Bronislaw. Les imaginaires sociaux. Mémoires et espoirs collectifs. Paris: Payot, 1984, especialmente p. 30-ss. Em outra dimensão teórica, as articulações entre o ser social e a formulação histórica e indeterminada da consciência social foram abordados por Edward P.Thompson no livro A Miséria da Teoria.Trad.W.Dutra. Rio de Janeiro:Zahar, 1981.

28. Sobre os museus como locais de peregrinação turística e simbólica, ver: HORNE, Donald. The great museum. The representation of history. London/Sidney: Pluto Press, 1984. Sobre a concepção de imaginação e imaginação histórica, consultar a obra de Baczko já mencionada, bem como Stephen Bann, As invenções da História. Trad. F. Villa-Lobos. São Paulo: UNESP, 1994. que as pessoas mantiveram com o ambiente museológico, no qual representações iconográficas e objetos, pelas impressões estéticas e emocionais que proporcionam, motivam também um trabalho de observação, reflexão e recomposição de antigas experiências entre o eu e a história.

Além disso, procurei seguir à risca a proposta de Ecléa Bosi no sentido de não tomar "nenhum documento de confronto dos fatos relatados que pudesse servir de modelo, a partir do qual se analisassem distorções e lacunas"26. Como bem observou a autora, os livros de história registram igualmente versões, interpretações, pontos de vista. Interessava-me o conteúdo e a forma daquilo que pudesse ser lembrado sobre a Independência e a data de 7 de setembro, daquilo que os entrevistados, nos instantes fugidios de duração da conversa, poderiam expor. Até porque, não iniciei essa atividade tomando como ponto de partida uma determinada interpretação do processo histórico em questão. Foi precisamente o contrário: esperava, com as entrevistas, levantar, ou ao menos identificar preliminarmente, os prováveis suportes culturais e políticos de um ritual cívico centenário e investigar as leituras da história do Brasil que ainda davam sustentação para o impacto provocado pela decoração interna do Museu.

A primeira questão apontada pelas entrevistas diz respeito à diversidade do público visitante. As pessoas com as quais conversei residem em diferentes bairros da cidade, alguns localizados a enorme distância do lpiranga. Muitas haviam se deslocado do interior de São Paulo ou de outras regiões, como o Rio Grande do Sul, por exemplo. Mas, chamou-me a atenção a diferenciação social existente entre elas, o que torna problemático o estabelecimento de qualquer relação direta entre a prática da visitação e determinados segmentos sociais. Evidenciou-se que os apelos estético, histórico e emocional exercidos pelo edifício e pelos acervos encantam tanto a empregadas domésticas e advogados quanto a operários e engenheiros. Essas pessoas que conhecem o Museu Paulista como "Museu do lpiranga" ou como "Museu da Independência", ainda em função das tradições e estórias que cercam o Monumento,vivem e trabalham sob condições díspares e antagônicas.

Observando-as, é visível a diferença nos trajes, no gestual, bem como nas mãos e rostos que, em algumas, carregam as cicatrizes do labor cotidiano. A despeito disso, no entanto, são capazes de dividir os mesmo espaços e admirar, com igual curiosidade e entusiasmo, objetos e imagens expostos, o que sugere a complexidade tanto dos nexos que articulam modos de existência e imaginário ${ }^{27}$ quanto dos liames que entrelaçam o Museu e seus freqüentadores. Até porque não se trata apenas da comunhão difusa de uma prática engendrada histórica e culturalmente. Em sua maior parte, os entrevistados estavam acompanhados por crianças e jovens, filhos, sobrinhos ou netos, indicando implicações outras para a experiência de participar de ritual evocativo. Ao lado da ida ao lpiranga significar literalmente uma viagem para muitos, a presença no lugar a partir do qual a "nação" teria se forjado desdobra-se em viagem pelo tempo, em "vivência" momentânea do passado, compartilhada oral e visualmente pelo grupo familiar, imprimindo-se carga afetiva à transmissão da "imaginação histórica"28.

Relaciona-se a essa circunstância o segundo problema proposto pelo teor das entrevistas. Os depoimentos apontaram para a fragmentação, quase individualizada, das versões sobre a Independência. É possível circunscrevê-los a um espectro cultural e a referências historiográficas comuns, pois podem ser identificados vestígios de registros produzidos pela educação escolar e pelos 
diferentes meios de comunicação, a exemplo de datas e nomes de protagonistas. Entretanto, pareceram-me muito presentes os liames entre os depoimentos e um universo multifacetado transmitido oralmente louvir dizer/ ser informado por pais, avós e parentes) e recriado por visitas anteriores ao Museu. Todos os entrevistados apresentaram uma interpretação, mas os caminhos traçados foram tão variados que se revelou, mais uma vez, o peso da "imaginação histórica" a animar o jogo de sentidos pela mediação do qual o passado foi recuperado. Cada um a seu modo recorreu à "invenção" para produzir linhas de continuidade ou de ruptura entre aquilo que parece ser um passado distante e difícil de precisar e a fluidez do presente vivido.

Como observou Bazcko, "a atualização do passado por meio de suas representações e símbolos conduz à confirmação de valores considerados como essenciais à identidade e à cultura nacionais" 29 . E talvez seja essa uma das vias para a compreensão de um dos significados da reiteração anual do "ritual cívico" de 7 de setembro. Além disso, o mesmo autor oferece sugestivas considerações acerca da importância da oralidade e dos vínculos entre as gerações na conformação da "imaginação histórica" e da memória individual e coletiva.

\begin{abstract}
[...] La fonction unificatrice de la mémoire collective et de ses symboles se manifeste remarquablement dans les rapports que s'établissent entre les générations. On pourrait, en effet, distinguer la "mémoire courte" de la "mémoire longue". La première s'organise autour d'une expérience commune, de régle, celle d'un "événement choc", vécu par une classe d'âge à l'époque de sa jeunesse et qui, du coup, définit cette classe précisément comme une génération. L'autre s'établit par tout un mécanisme social de transmission de sumboles, mythes, rituels, etc., propres à une communauté définie, qui se réfère à un passé lointain, notadamment celui des "origines", et réactualise. Entre les deux, on pourrait, peut-être, distinguer une mémoire de durée moyenne, celle qui se forme dnas les contacts directs entre deux ou trois générations successives, notamment par la transmission de souvenirs. Définitions provisoires qui ne prétendet guére à trop de précision mais qui se proposent, tout au plus, de faire valoir l'importance capitale du concept même de génération, trop délaissé par les sciences sociales, pour toute la analyse de la mémoire collective $[\ldots]^{30}$.
\end{abstract}

Baczko formula reflexões que privilegiam a dimensão do espectro simbólico e cultural comum a iluminar a memória coletivamente compartilhada, particularizando a importância dos modos de transmissão oral no interior da convivência entre gerações diferentes, traços presentes de forma marcante nas entrevistas. Entretanto, e em uma outra direção, é a obra de Maurice Halbwachs, ${ }^{31}$ que auxilia a referenciar os vínculos complexos, cambiantes e indeterminados entre os "quadros sociais" e a singularidade fragmentária da memória individual. Ao mesmo tempo em que se refere à oralidade assim como aos suportes afetivos da memória individual proporcionados pela convivência familiar e entre gerações, Halbwachs sugere que não se poderia tomar a memória coletiva como sendo única. A seu ver, em razão da pluralidade de articulações que se estabelecem ao longo da vida entre o sujeito, seus grupos de convívio e a "comunidade nacional", haveria memórias coletivas que mesmo envolvendo as memórias individuais com elas não se confundiriam.

Por outro lado, segundo Halbwachs, os eventos, datas e comemorações que formam parcela da memória histórica preservada e atualizada pela sociedade podem, a princípio, revestir-se de exterioridade em relação ao sujeito, pois este os conheceria ou aprenderia a reconhecê-los por intermédio de palavras, imagens, relatos e leituras emprestados a outrem e a seu meio social. E essa história ensinada
29. BACZKO, Bronislaw. Ob. cit., p. 229.

30. Id., ibid., p. 226-227. Grifos no original.

31.HALBWACHS, Maurice. A memória coletiva. Trad. L.L. Schaffter. São Paulo: Vértice, 1990. p. 53-ss. 
32. Id., ibid.

33. BOSI, Ecléa. Ob.cit., cap. 1 e 2; HALBWACHS, Maurice. Ob.cit., p. 53-ss. e aprendida seria um suporte muito frágil para a memória e os trabalhos de rememoração que se ancoram na "história vivida".

No entanto, e essa parece-me constituir reflexão primordial para a problematização dos depoimentos e da tradição celebrativa em torno do Museu, Halbwachs ponderou que a exterioridade entre o sujeito que lembra e a história rememorada é aparente, pois datas, nomes e formas não se mostram isoladamente, compondo "correntes de pensamento e de experiências" pela mediação das quais a pessoa se conforma à condição de sujeito ${ }^{32}$. Nesse sentido, mesmo episódios, símbolos, rituais e significações que remetem a um passado distante e intangível podem ser incorporados, recriados e transformados no âmbito da "história vivida". E, certamente, dentre outras tantas configurações, os museus de história, como o Museu Paulista, auxiliam essa operação matizada, fragmentada e carregada de emoções e apelos afetivos que pode conduzir o sujeito a identificarse com "comunidade nacional".

Mais do que evidenciar que é o momento presente que ilumina, atualiza e desencadeia o curso da memória, os depoimentos indicam que cada um dos entrevistados, a seu modo, buscou no arsenal cultural e simbólico que havia acumulado durante sua vida pessoal os elementos para estabelecer um diálogo entre passado e situação vivida. Por essa via, reencontramos Bosi e Halbwachs, ${ }^{33}$ para quem a consciência atual do sujeito que rememora dispõe da imaginação histórica e do conjunto de representações que incorporou e reinterpretou para filtrar e recriar imagens e identificações em relação ao passado.

No caso particular do tema da Independência, as considerações desses autores conduzem à percepção da força e solidez dos "quadros sociais da memória" subjetiva e ao reconhecimento do peso das instituições e tradições na formação do sujeito que se relaciona com os demais e com sua história, construindo e reconstruindo a cada momento sua própria identidade pessoal e coletiva, por intermédio de práticas e concepções que povoam de modo visível (monumentos, imagens, museus, objetos) e invisível (fundamentos das relações intersubjetivas) a sua apreensão do passado e a sua visão sobre o passado.

Nesse sentido, a constatação por parte da maioria dos entrevistados de que os elos entre passado e presente se perderam, mas paradoxalmente continuam vivos, em razão da percepção de que somos hoje o resultado daquilo que se processou anteriormente, pode ajudar a compreender a constante visitação ao Museu, bem como a reatualização de tradições celebrativas, uma vez que o espaço museológico estaria destinado a promover uma experiência singular em relação ao passado. Para algumas das pessoas com as quais conversei, essa experiência se realizou pela mediação de objetos e imagens ali expostos e interpretados como vestígios de uma realidade que por força do tempo se esgarçou. Para outros, os acervos e o próprio edifício eram indicadores de uma maneira de contar o que ocorreu no passado, não se confundindo necessariamente com a realidade do passado ou do presente.

Os depoimentos sugerem que a Independência - entendida como "fato", como tema ou como questão política não resolvida - continua a exercer enorme capacidade de mobilização junto ao público visitante. Mas as falas dos entrevistados superam essa dimensão, mostrando mediações mais nuançadas, pois vários deles interrogaram o alcance atual da Independência em razão da ausência de democracia, de carências sociais e educacionais, da falta de direitos da população ou de sua não observância por parte de governantes e 
parlamentares. Foram carências e ausências que provocaram a percepção de que a Independência não se completou, situação esta relacionada à visibilidade de profundo distanciamento entre sociedade e Estado e entre a história contada no Museu e situações vivenciadas cotidianamente.

Além disso, os depoimentos enriquecem a compreensão e problematização do papel contemporâneo desempenhado pelos museus de história - e pelo Museu Paulista - quer como locais onde o passado poderia ser visualizado por meio de narrativa linear e "realista", quer no sentido de "lugares de memória", capazes de condensar o que deveria ser guardado e esquecido. "[...] $\bigcirc$ que eu estou vendo é toda a história, quase que desde a chegada...os descobrimentos [...] as bandeiras [...]" ( Sr. Edmundo, $31 / 7 / 92)$.

A primeira impressão provocada por uma fala como essa é a de que telas e esculturas, distribuídas no saguão e nas paredes da entrada e da escadaria do edifício (pois o entrevistado mencionou especificamente as figuras dos bandeirantes e as representações dos primeiros colonizadores), seriam a reprodução fiel do passado tal como foi. Mesmo o depoimento do Sr. Carlos, citado abaixo, conduz à suposição de que em um museu, diferentemente de outras formas de abordagem da história, como a feita no ambiente escolar, por exemplo, mantémse um contato direto com o passado, como se objetos e iconografia, sem intermediários, "mostrassem" e dessem concretude à existências pretéritas:

[...] Na minha escola, nunca ninguém na minha escola me trouxe ao museu. Acho que uma professora de história que esteja falando sobre a Independência do Brasil, no mínimo, no currículo dela, tem de programar uma visita ao museu para mostrar como é que era. Aqui há vários dados que você poderia obter para fazer um bom trabalho [...] ( Sr. Carlos, 20/8/92).

Aparentemente, a associação imediata entre história e o que "existiu antes" transforma o Museu em templo daquilo que a memória social reteve e que constitui fragmento fidedigno das heranças culturais e do patrimônio a serem preservados $^{34}$. Como templo o Museu assumiria, tão-somente, o estatuto de lugar que projeta lembranças e conhecimentos, interiorizados pelo olhar e pela experimentação de sensações. Concomitantemente, porém, os depoimentos sinalizam para uma outra significação do espaço museológico e das narrativas que projeta, pois é ali que se expressam de forma mais evidente as diferenças e mudanças que o tempo impõe nos modos de vida. "[...] Eu venho quase todos os domingos. E interessante ver, assim, parte de nossa história, tudo o que existiu antes, o jeito deles, os móveis, tudo [...]" ( Sr. Asdrubal, 7/9/92).

[...] Vim ao museu umas cinco vezes mais ou menos. Duas vezes com minha família e desde quando eu era criança já tinha vindo aqui... Costumo vir no 7 de setembro. Traz curiosidades do tempo antigo, coisas que a gente não viu como eram feitas. As coisas que eles usavam antigamente, e que hoje usa completamente diferente, então traz muita curiosidade... O que mais me chamou a atenção foram os quadros, que retratam bem melhor as coisas de antigamente....Eu acabei de dizer para meus filhos. Eu me lembro muito bem que quando vim aqui e era criança muitas coisas mudaram aqui, de lugar, já não são as mesmas coisas. E hoje eu estou trazendo eles, como já trouxe quando eram pequenos e então eu falo para eles se recordarem disso aqui porque eu acredito que quando estiverem com mais idade, 20 anos, 25 anos, eles vão ver que alguma coisa mudou [...] ( Sr. Adilson, 7/9/92).

A visita ao Museu parece proporcionar vínculos de distanciamento e de aproximação entre presente e passado, assim como a sensação de "reviver" situações que se perderam inexoravelmente, mas nem por isso deixaram de existir.
34 .Reflexões e discussões sobre os museus históricos e seus significados, podem ser encontradas em: HORNE, Donald. Ob. cit.; JEUDY, HenriPierre. Memórias do Social. Trad. M. Cavalcanti. Rio de Janeiro: Forense, 1990; MENESES, Ulpiano Toledo Bezerra de. Do teatro da memória ao laboratório da história: a exposição museológica e o conhecimento histórico. Anais do Museu Paulista, São Paulo, n. 2, p. 9-84, 1994/1995 e n. 3, p. 83121; SUANO, Marlene. $O$ que é museu? São Paulo: Brasiliense, 1990; VIEL, Anette; DE GUISE, Céline (Dir.). Muséo-séduction/ Muséo-réflexion.Canadá: Musée de la civilisation, 1992; DAGOGNET, François. Le musée sans fin. Paris: Champ Vallo, 1993; KAPLAN, Flora (Ed.). Museums and the making of "ourselves". London/ New York: Leicester Universy Press, 1994; BREFE,Ana Claúdia. Museu históricos na França: entre a reflexão histórica e a identidade nacional. Anais do Museu Paulista, São Paulo, 1997, n. 5, p. 175-204. 
35. D. Celestina referiu-se, sem dúvida, à época em que, conforme a organização dada por Taunay, as salas de exposição reuniam vitrinas completamente preenchidas por documentos textuais e objetos e nas paredes achavam-se, lado a lado e em profusão, retratos, paisagens e mapas.
[...] Nós estamos aqui passando férias, uma temporada, e resolvemos fazer uma visita... Traz muitas lembranças de nossa história, de nossos antepassados... Não vivemos naquela época, mas igualmente sentimos o estar naquela época. [...] Os quadros, as figuras, as peças de armamento e muitas outras coisas que me fascinaram pela história do Brasil. Isto contribui para nós podermos mostrar [às crianças] uma história muito bonita do nosso país [...] (Sr. Carlos Eduardo, 7/9/93).

[...] Desde os 7 anos de idade que eu não saio do museu... Eu gosto daqui, acho bonito. Eu admiro os quadros, os brazões, admiro a louça antiga. E tem muita coisa aqui para a gente ver! Para ver e voltar sempre porque cada vez que a gente vai revendo essas coisas todas, você vai guardando mais e mais coisas importantes...Aqui é tudo sobre a nossa cultura, o nosso passado, o começo da nossa história. Aqui diz tudo, aqui está marcado tudo. É gostoso rever a história... $O$ povo tem que participar, tem que vir ao museu, tem que saber a nossa história [...] (Da. Angelina, 7/9/93).

[...] É importante vir ao museu porque você revive, você cultua momentos importantes. Principalmente em termos culturais, em termos da memória para um país acho que isso é de suma importância: reviver, revitalizar esses momentos [...] ( Sr. Sérgio, 7/9/93).

Mas deparei também com um depoimento em que a visita ao Museu havia se revelado uma decepção: o entrevistado, provavelmente por imaginar que o edifício havia sido residência da família imperial, de D.Pedro ou de outro qualquer protagonista, indicava um certo inconformismo por não encontrar, em sua interpretação, "alguma coisa como realmente era". A seu ver, "a história havia sido mexida", as salas e quartos não reuniam os objetos que esperava encontrar nos lugares onde supostamente deveriam estar.

[...] É praticamente a primeira vez porque eu já vim, mas era muito pequeno [...] Eu procurei mostrar [para as filhas] logo subindo a escadaria o D.Pedro I, o quadro da Da. Leopoldina com os filhos... O que nós estamos comentando e que gostaríamos de ver é alguma coisa como realmente era, as salas, como realmente eram montadas, e isso a gente não tem no museu. Tem muito mais inclusive da história recente...moedas...selos...mas nós gostaríamos de ver uma parte da história sem ser mexida, como existe em Campos do Jordão, no Palácio. São salas como realmente elas eram, os quartos... para as crianças saberem como eles viviam [...] (Sr. Agenor, 7/9/ 93).

Essa foi, porém, uma voz isolada, diante de narrativas que, muitas vezes, com orgulho e emoção, se referiram ao Museu como algo familiar, local visitado em inúmeras ocasiões e onde a maioria dos entrevistados esperava encontrar não novas exposições necessariamente, mas a possibilidade de reinterpretar aquilo que haviam conhecido na infância, pois acredita-se que o passado histórico em função de sua existência efetiva não poderia se alterado nem em sua substância nem nos vestígios que o testemunham. O que levou $\mathrm{Da}$. Celestina a comentar: "[...] Eu achei que desde a época em que vim aqui está muito diferente agora. Antes parece que tinha mais...Agora não tem tanta coisa como antigamente [...] $(7 / 9 / 92)^{\prime \prime 35}$.

Nas falas que registrei foram constantes expressões como "reviver", "cultuar", "rever", "guardar" e "transmitir". Além disso, as "coisas" expostas móveis, "louças", retratos - parecem adquirir vida própria, atribuindo-se a elas a capacidade de contar e assinalar momentos da história. No entanto, essas palavras não estão necessariamente associadas a uma ação contemplativa e também não aparecem como sinônimos da concepção de que no Museu o passado pudesse ser vislumbrado tal como foi. Conforme observou Ecléa Bosi, "reviver" 
significa refazer no presente situações, sentimentos e impressões que se revestem de contornos outros ${ }^{36}$, posta a condição incontornável de que o tempo e o passado não voltam, a não ser como representações ${ }^{37}$.

Assim, se as reflexões de Bann sobre a configuração de museus de história destinados a promover a "visualização do passado como realidade experiencial"38 revelam-se enriquecedoras para a problematização da recorrência do ritual evocativo de 7 de setembro, e para a sistematicidade adquirida pela visistação ao Museu, independentemente de chamamentos publicitários específicos, os depoimentos indicaram que as experiências que os espaços museológicos propiciam não seguem percurso único e, portanto, não cabe ser simplificadas. Além disso, ainda que o público se deixe envolver pelos apelos políticos e estéticos ali mobilizados, permanece aberta a possibilidade de releituras que necessariamente não coincidem com os desígnios históricos e políticos ali inscritos.

Os depoimentos sugerem que o olhar, as percepções e as reflexões dos visitantes não se submetem necessariamente à "realidade experiencial do passado" e ao ordenamento conceitual e espacial projetado pelo edifício, pela decoração interna e mesmo por muitas das exposições. As pessoas que entrevistei registraram impressões fragmentadas de objetos, retratos e imagens, e esta forma de percepção acaba por nuançar narrativas históricas aparentemente monolíticas e "realistas", tais como as que se apresentam no saguão e na escadaria do prédio. Além disso, em várias das entrevistas evidenciou-se a noção de que o Museu narra a história, mas essas narrativas não se confundem com o que aconteceu no passado, até porque as diferenças entre passado/ presente não são meramente formais.

Quando alguns dos entrevistados mencionaram que o Museu resguarda uma parte da história e que ali é possível observar como "eles" viveram, o pronome não se refere apenas a uma questão de ordem temporal. Indica o reconhecimento de que há diferenças sociais e políticas, de que os "grandes homens" representados nos retratos, em razão da posição que ocuparam, eram os que tinham acesso a "coisas" como móveis, porcelanas e brazões, e que a acessibilidade ao poder usufruído em virtude do requinte da vida material foi um dos motivos de terem superado a mortalidade.

Nesse sentido, conforme observou Poulot (2003) $)^{39}$, os museus de história hoje estão atravessados por tensões e confrontos. Por um lado, são tênues os trabalhos de articulação entre museus de história e historiografia, uma vez que as representações do passado projetadas ou inscritas nessas instituições, a exemplo do Museu Paulista e de sua ornamentação interna, estão em contradição ou não espelham os atuais desenvolvimentos da pesquisa nos vários "campos e canteiros" da história ${ }^{40}$. Por outro, as dissonâncias não dizem respeito apenas ao âmbito do conhecimento historiográfico, uma vez que estão presentes, igualmente, no modo pelo qual o Museu e sua atuação vêm sendo interpretados pelo imenso público que o visita e que mantém com a instituição e o lugar fortes vínculos sociais e emocionais. Talvez, entretanto, seja este um momento privilegiado para buscar um diálogo entre narrativas e saberes históricos discrepantes e fazer dos museus de história centros de referência capazes de, retomando Poulot, "registrar nosso tempo, desenvolver sua história e reescrevê-la" 41 .
36. BOSI,Ecléa.Ob.cit.,p. 17 -ss.

37. LEFORT, Claude. As formas da história, especialmente cap. XI.

38. BANN, Stephen. As in venções da história. Ensaios sobre a representação do passado. Trad. F. Villa-Boas. São Paulo: UNESP, 1994. p. 153-178.

39. POULOT, Dominique. Museu, nação, acervo. In: BITTENCOURT, J. N.; BENCHETRIT, S.;TOSTES, V. (Org.). História representada: o dilema dos museus. Rio de Janeiro: Museu Histórico Nacional, 2003. p. 26-62.

40. Expressão usada por D. Julia e J. Boutier para intitular Passados recompostos: campos e canteiros da história, obra que organizaram sobre questões atuais da teoria e metodologia da história e que foi editada pela Universidade Federal do Rio de Janeiro, em 1998, com prefácio de Francisco Falcón.

41. POULOT, Dominique. Ob. cit., p. 53-54. 


\section{FONTES}

DÉNIS, Pierre. Le Brésil ao XXe. Siècle (1906). Paris:Armand Colin, 1910.

DEPOIMENTOS de 40 visitantes do Museu Paulista/USP, produzidos entre julho de 1992 e setembro de 1995.

FORREST, Archibald Stevenson.A tour through south America (1912). In: BRUNO, Ernani da Silva. Memória da Cidade de São Paulo. Depoimentos de moradores e visitantes, 1553/1958. São Paulo: Prefeitura Municipal/DPH, 1981.

IHERING, Hermann von.O Museu Paulista nos anos de 1903 a 1905. Revista do Museu Paulista, São Paulo, v.VI, 1907.

IHERING, Hermann von. O Museu Paulista nos anos de 1910, 1911 e 1912. Revista do Museu Paulista, São Paulo,Tomo IX, 1914.

RELATÓRIOS apresentados por Afonso de Escragnolle Taunay ao governo do Estado de São Paulo, referentes ao Museu Paulista durante os anos de 1917-1922. Serviço de Documentação Textual e Iconografia do MP/USP.

WRIGHT, Marie Robinson.The New Brazil (1902). In: BRUNO, Ernani da Silva.Memória da Cidade de São Paulo. Depoimentos de moradores e visitantes, 1553/1958. São Paulo: Prefeitura Municipal/ $\mathrm{DPH}, 1981$.

\section{REFERÊNCIAS}

ALVES, Ana Maria de Alencar. O Ipiranga apropriado. Ciência, política e poder. O Museu Paulista, 1893/1922. São Paulo: Humanitas/PPGHS/USP, 2001.

ANDERSON, Benedict. Comunidades imaginadas. Reflexões sobre el origem y la difusión del nacionalismo. México: Fondo de Cultura Econômica, 1993.

BACZKO, Bronislaw. Les imaginaires sociaux. Mémoires et espoirs collectifs. Paris: Payot, 1984.

BANN, Stephen. As invenções da história.Tradução de F.Villa-Lobos. São Paulo: UNESP, 1994.

BITTENCOURT, Circe Maria F. Pátria, civilização e trabalbo. O ensino de História nas escolas paulistas, 1917/1939. São Paulo: Loyola, 1990.

BOSI, Ecléa.Memória e Sociedade. Lembranças de velhos. São Paulo:TA Queiróz, 1983, p. 251.

BOSI, Ecléa. O tempo vivo da memória. Ensaios de psicologia social. São Paulo:Ateliê Editorial, 2003.

BREFE, Ana Claúdia. Museus históricos na França: entre a reflexão histórica e a identidade nacional. Anais do Museu Paulista, São Paulo, n. 5, p. 175-204, 1997.

BREFE, Ana Cláudia Fonseca. Um lugar de memória para a nação. O Museu Paulista reinventado por Affonso d'Escragnolle Taunay. 1999. 304 f. Tese (Doutorado) - Universidade de Campinas, Campinas, 1999. 
CADERNOS de História de São Paulo, São Paulo, v. 1-5, 1992/1996.

CHOAY,Françoise. A alegoria do patrimônio. Tradução de L.V.Machado. São Paulo:UNESP/Estação Liberdade, 2001.

DAGOGNET, François. Le musée sans fin. Paris: Champ Vallo, 1993.

ELIAS, Maria José.Museu Paulista: memória e história. 1996.473 f.Tese (Doutorado) - Universidade de São Paulo, São Paulo, 1996.

FERREIRA, Antonio Celso.A epopéia bandeirante: letrados, instituições, invenção histórica, 1870/ 1940. São Paulo: UNESP, 2002.

HALBWACHS, Maurice. A memória coletiva. Tradução de L. L. Schaffter. São Paulo:Vértice, 1990.

HARTOG, François. Tempo e História: como escrever a história da França hoje? História Social, Campinas, n. 3, p.127-154, 1996.

HOBSBAWM, Eric; RANGER,Terence (Org.). A invenção das tradições. Tradução de C. Cavalcanti. Rio de Janeiro: Paz e Terra, 1984.

HORNE,Donald. The great museum. The re-presentation of history. London/Sidney:Pluto Press, 1984.

JANOTTI, Maria de Lourdes; ROSA, Zita de Paula. História oral: uma utopia? Revista Brasileira de História, São Paulo, n. 25/26, p. 3-20, 1992/1993.

JEUDY, Henri-Pierre. Memórias do Social.Tradução de M. Cavalcanti. Rio de Janeiro: Forense, 1990.

JULIA, Dominique; BOUTIER, Jean. (Org.). Passados recompostos: campos e canteiros da história. Rio de Janeiro: UFRJ/FGV, 1998.

KAPLAN,Flora (Ed.).Museums and the making of “ourselves”. London/ NewYork:Leicester Universy Press, 1994.

LEFORT, Claude. As formas da história. Tradução de M. Chauí e L.R.Salinas Fortes. São Paulo: Brasiliense, 1979.

LOPES, Maria Margareth.O Brasil descobre a pesquisa científica. Os museus e as ciências naturais no século XIX. São Paulo: Hucitec, 1999.

LUCA,Tania Regina de.A Revista do Brasil: um diagnóstico para a (n)ação. São Paulo: UNESP, 1999.

MENEGUELLO, Cristina.Da ruína ao edifício. Neogótico, reinterpretação e preservação do passado na Inglaterra vitoriana. 2000. Tese (Doutorado) - Universidade de Campinas, Campinas, 2000.

MENESES, Ulpiano Toledo Bezerra de. O museu na cidade/a cidade no museu:para uma abordagem histórica dos museus de cidade. Revista Brasileira de História, São Paulo, v. 5, n. 8/9, p. 197-206, set/1984-abril/1985.

MENESES, Ulpiano Toledo Bezerra de. Do teatro da memória ao laboratório da história: a exposição museológica e o conhecimento histórico. Anais do Museu Paulista, São Paulo,n. 2, p. 9-84 e n.3, p. 83-121, 1994/1995. 
MORSE, Richard. Formação bistórica de São Paulo. São Paulo: Difel, 1970.

NAGLE, Jorge. A educação na primeira república. In: FAUSTO, Boris (Org.). História geral da civilização brasileira. São Paulo: Difel, 1970. tomo III, v. 2, p. 259-292.

NORA, Pierre (Org.). Les Lieux des Mémoires. Paris: Gallimard, 1984. p.VIII-XLII.

OLIVEIRA, Cecilia Helena de Salles. O espetáculo do Ypiranga: mediações entre história e memória. 2000. 288 f. Tese (Livre-Docência) - Museu Paulista, São Paulo, 2000.

OLIVEIRA, Cecilia Helena de Salles. O Museu Paulista da USP e a memória da Independência. Cadernos do CEDES, São Paulo, v. 22, n. 58, p.65-80, dez. 2002.

OLIVEIRA FILHO, José Costa. O edifício do Museu Paulista: um pouco da história do edifíciomonumento de Bezzi. São Paulo: USP, 2000.

POULOT, Dominique. Museu, nação, acervo. In: BITTENCOURT, J. N.; BENCHETRIT, S.; TOSTES, V. (Org.). História representada: o dilema dos museus. Rio de Janeiro: Museu Histórico Nacional, 2003. p. 26-62.

POULOT, Dominique (Ed.). Patrimoine et modernité. Paris: L'Harmattan, 1998.

PRADO, Maria Ligia Prado. América Latina no século XIX. Tramas, telas e textos. São Paulo: EDUSC/ EDUSP, 1999.

QUEIROZ, Suely Robles. São Paulo. Madrid: Editorial MAPFRE, 1992.

SCHWARZTEIN, Dora. História oral, memória e histórias traumáticas. História Oral. São Paulo, n. 4 , p. 73-93, 2001.

SEVCENKO, Nicolau. Orfeu extático na metrópole. São Paulo, sociedade e cultura nos frementes anos 20. São Paulo: Companhia das Letras, 1992.

SUANO, Marlene. O que é museu? São Paulo: Brasiliense, 1990.

THOMPSON, Edward P. A miséria da teoria.Tradução de W. Dutra. Rio de Janeiro: Zahar, 1981.

VIEL, Anette; DE GUISE, Céline (Dir.). Muséo-séduction/Muséo-réflexion. Canadá: Musée de la civilisation, 1992.

Artigo apresentado em 8/2003. 
História nacional em São Paulo: o Museu Paulista em 1922

Ana Cláudia Fonseca Brefe

O texto trata dos cinco primeiros anos da gestão de Affonso de Escragnolle de Taunay no Museu Paulista, de 1971 a 1922. Neste curto período, essencial para entender o perfil que o Museu adquiriu posteriormente, Taunay deu à vetusta instituição do lpiranga os principais contornos de um museu histórico, ou mais precisamente, de um "lugar de memória" nacional, pretendendo fixá-lo como lugar de origem da nação brasileira e, ao mesmo tempo, concedendo a São Paulo o ansiado destaque no cenário nacionál. A autora aborda assim as principais transformações que foram feitas no Museu, em relação à diretoria anterior do naturalista Hermman von Ihering, acompanhando ano a ano abertura de novas salas dedicadas à história nacional e paulista e a realização paulatina da decoração histórica dos espaços monunentais do Museu para a festa do centenário da Independência brasileira em 1922.

PALAVRAS-CHAVE: Museus históricos. Museu Paulista. Centenário da Independência brasileira. História nacional.

Anais do Museu Paulista. São Paulo. N. Sér. v. 10/11. p.79-103 (2002-2003).

National history of São Paulo: the Museu Paulista in 1922

\section{Ana Cláudia Fonseca Brefe}

The essay is about the five first years of Affonso de Escragnolle de Taunay's term in the Museu Paulista, from 1971 to 1922. In this short period, essential to understand the profile the museum acquired later, Taunay gave the ancient institution of Ipiranga the main outlines of a museum of History, or even more precisely, a "place of national memory", intending to establish it as a place of origin of the Brazilian nation and, at the same time, granting São Paulo with the longed outstanding place in the national scenario. The author deals this way with the main transformations that had been carried out in the museum, in relation to the naturalist Hermman von Ihering's former term as a director, following year by year the opening of new room dedicated to the national history and the São Paulo's realization of the historic decoration of the monumental spaces of the museum for the Brazil's Independence centenary party in 1922.

KEYWORDS: History Museums. Museu Paulista. Centenary of Brazil's Independence. National History. Anais do Museu Paulista. São Paulo. N. Sér. v. 10/11. p.79-103 (2002-2003).

Museu Paulista: espaço de evocação do passado e reflexão sobre a história

\section{Cecilia Helena de Salles Oliveira}

Oartigo discute as relações que historicamente se estabeleceram entre o Museu Paulista da USP e seus freqüentadores, referenciando-se em depoimentos de visitantes, produzidos no período entre 1992 e 1995. O argumento central é o de que a interação secular entre a instituição e segmentos diferenciados de público fundamenta-se em tradições celebrativas criadas em torno da Independência e, também, em amplo e complexo cenário de interpretações e expectativas sobre os sentidos dos museus de História

PALAVRAS-CHAVE: Museu Paulista. Museu de história. Memória. Conhecimento histórico. Fontes orais. Anais do Museu Paulista. São Paulo. N. Sér.v. 10/11.p.105-126 (2002-2003).

Museu Paulista: place of evocation of the past and reflection about History

\section{Cecilia Helena de Salles Oliveira}

This article focuses the relationships historically established between the Museu Paulista of USP and its visitors, based on personal testimonies, made in the period from 1992 to 1995. The central argument is that the secular interaction between the institution and the different classes of the audience bases itself on celebrative traditions created in regard of the Independence and, also, on a large and complex scenario of interpretations and expectations about the meanings of History museums. 